\title{
Peroperatieve en oncologische resultaten van de robotgeassisteerde partiële nefrectomie en robotgeassisteerde radicale nefrectomie in een Nederlands hoogvolumecentrum
}

\author{
Lucy K. Pellikaan ${ }^{1} \cdot$ Melanie Gan $^{1} \cdot$ Patrick Leenen $^{2} \cdot$ Dies van den Ouden $^{1} \cdot$ O. Sjoerd Klaver ${ }^{1}$ Roel Engel $^{1}$ \\ Diederik C. D. de Lange ${ }^{1}$
}

Published online: 2 August 2016

(C) The Author(s) 2016. This article is available at SpringerLink with Open Access.

Samenvatting Deze studie is uitgevoerd om het resultaat te beschrijven van robotgeassisteerde partiële nefrectomie (RAPN) en van robotgeassisteerde radicale nefrectomie (RARN). Hiertoe is een prospectieve data-analyse uitgevoerd op de uitkomsten van 200 patiënten die een RAPN en 116 patiënten die een RARN ondergingen tussen februari 2011 en april 2015. De operatieduur en het bloedverlies waren $133 \mathrm{~min}(\mathrm{IQR}=109-164)$ en $100 \mathrm{ml}$ $(\mathrm{IQR}=40-250)$ bij RAPN en 132 min (IQR $=104-163)$ en $75 \mathrm{ml}(\mathrm{IQR}=1,3-200)$ bij RARN. De warme ischemietijd bedroeg 16 min (IQR = 12-20) bij RAPN. Peroperatief trad bij RAPN eenmaal en bij RARN tweemaal een complicatie op. Hooggradige postoperatieve complicaties kwamen voor na RAPN bij $8 \%$ en na RARN bij 5,2\% van de patiënten. Mediane opnameduur was drie dagen. De tumordiameter bedroeg $32 \mathrm{~mm}$ (IQR = 23-44) bij RAPN en $68 \mathrm{~mm}(\mathrm{IQR}=49,5-90)$ bij RARN. De nierfunctie nam postoperatief af, maar stabiliseerde na drie maanden. $\mathrm{Na}$ een mediane follow-up van 12 maanden was $85,4 \%$ van de patiënten ziektevrij, was $4,2 \%$ progressief en was $3,3 \%$ overleden vanwege renaalcelcarcinoom. De conclusie luidt dat analyse van robotgeassisteerde nierchirurgie leidt tot een korte operatieduur, minimaal bloedverlies, weinig complicaties en goede oncologische uitkomsten.

Trefwoorden robotgeassisteerde partiële nefrectomie . robotgeassisteerde radicale nefrectomie $\cdot$ oncologie .

RENAL-score · PADUA-score

drs. Lucy K. Pellikaan

lucypellikaan@hotmail.com

1 afdeling Urologie, Maasstadziekenhuis, Rotterdam, Nederland

2 Blok Social Society, Oostrum, Nederland
Perioperative and oncological outcomes of robotic partial and radical nephrectomy in a high volume center in the Netherlands

\begin{abstract}
The objective of this study was to describe outcomes of robot-assisted partial nephrectomy (RAPN) and robot-assisted radical nephrectomy (RARN). Prospective data were analyzed of 320 patients who underwent RAPN or RARN from February 2011 until April 2015. The median operative time and blood loss were $133 \mathrm{~min}(\mathrm{IQR}=$ 109-164) and $100 \mathrm{ml}(\mathrm{IQR}=40-250)$ for RAPN and $132 \mathrm{~min}(\mathrm{IQR}=104-163)$ and $75 \mathrm{ml}(\mathrm{IQR}=1,3-200)$ for RARN. In RAPN warm ischemic time was 16 min (IQR = 12-20), tumor size was $32 \mathrm{~mm}(\mathrm{IQR}=23-44)$. In RARN tumor size was $68 \mathrm{~mm}(\mathrm{IQR}=49,5-90)$. Postoperative high grade complications were noted in $8 \%$ of RAPN and 5,2\% in RARN. Renal function decreased after surgery, but stabilized after 3 months. Median follow-up was 12 months. Disease progression was observed in $4,2 \%$ of cases. 3,3\% died due to kidney cancer. The conclusion is that robot-assisted renal surgery is characterized by low operation time, minimal bloodloss, few complications and very acceptable oncological outcomes.
\end{abstract}

Keywords robot-assisted partial nephrectomy $\cdot$ robotassisted radical nephrectomy · oncology $\cdot$ RENAL-score . PADUA-score

\section{Introductie}

De primaire behandeling van gelokaliseerde niertumoren is radicale chirurgische resectie [1,2]. Nefronsparende therapie wordt aanbevolen bij tumoren kleiner dan $4 \mathrm{~cm}$ en ook bij tumoren tot $7 \mathrm{~cm}$ heeft een nefronsparende aanpak de 
voorkeur, indien deze aanpak technisch mogelijk is [1, 2]. In vergelijking met een radicale nefrectomie zijn behoud van nierfunctie en kwaliteit van leven beter na een partiële nefrectomie [3]. De vijfjaarsoverleving is vergelijkbaar [1]. Wanneer een partiële nefrectomie technisch niet haalbaar is, bijvoorbeeld bij een grotere of ongunstig gelegen tumor, vormt een radicale nefrectomie de behandeling van keuze [1-4].

De ontwikkeling van de robottechnologie maakt een grotere bewegingsvrijheid, natuurlijke oog-handcoördinatie en ergonomische houding van de operateur mogelijk [5-9]. Daarnaast verbetert visualisatie doordat het beeld niet alleen vergroot, maar ook driedimensionaal wordt weergegeven $[5,6,8,9]$. Een eventuele tremor van de operateur wordt gecorrigeerd en grote bewegingen op het bedieningspaneel kunnen worden omgezet naar microbewegingen in de patiënt $[8,9]$. Zo kunnen complexe tumoren die voorheen alleen via een open ingreep gereseceerd konden worden, dankzij de robot toch minimaal invasief verwijderd worden [10]. Introductie van de robotgeassisteerde chirurgie heeft geleid tot een toename van het aantal uitgevoerde partiële nefrectomieën [11].

Doel van deze studie is om per- en postoperatieve uitkomsten van de robotgeassisteerde partiële nefrectomie (RAPN) en robotgeassisteerde radicale nefrectomie (RARN) in een Nederlands hoogvolumecentrum te beschrijven.

\section{Materiaal en methoden}

Van de patiënten die een robotgeassisteerde radicale of partiële nefrectomie ondergingen in de periode tussen 1 februari 2009 en 30 april 2015 zijn alle data prospectief verzameld in een database. In totaal betrof het 320 patiënten: bij 200 werd een partiële nefrectomie verricht en bij 120 een radicale nefrectomie. Patiënten bij wie conversie naar een open procedure plaatsvond $(n=4)$ werden geëxcludeerd.

Uit het elektronisch patiëntendossier (EPD) werden de relevante data afgeleid, zoals operatieve kenmerken, laboratoriumuitslagen, complicaties en behandeling hiervan. Beeldvormende onderzoeken werden bestudeerd, waarna RENAL- en PADUA-scores prospectief werden toegekend om de complexiteit van de tumor vast te stellen. Voor de stadiëring werd de TNM-classificatie van niercelcarcinoom uit 2009 gebruikt [2]. Bij de uitkomsten werd bij de RAPN rekening gehouden met de complexiteit van de niertumor en bij de RARN met de mogelijke leercurve van het centrum.

Statistische analyse werd uitgevoerd met SPSS Statistics, versie 23 . Een $p$-waarde $<0,05$ werd gehanteerd als grens voor statistische significantie.

De follow-up was gericht op controle van de nierfunctie en vroegtijdige herkenning van een eventueel recidief of metastasen. De nierfunctie werd één dag, anderhalve maand, drie maanden, zes maanden en vervolgens halfjaarlijks na de operatie bepaald. Tot en met tien jaar na de operatie werden halfjaarlijks een echo abdomen en een thoraxfoto vervaardigd. Om onnodige stralingsbelasting te voorkomen, werd een CT-scan alleen op indicatie verricht.

\section{Techniek van de robotgeassisteerde partiële en radicale nefrectomie}

\section{Preoperatieve voorbereiding en robotinstrumentarium}

Indien mogelijk worden anticoagulantia preoperatief gestaakt. Antibioticaprofylaxe in de vorm van $1 \mathrm{~g}$ cefazoline wordt gegeven voor de inleiding. Preoperatief wordt een catheter à demeure geplaatst. In het ziekenhuis wordt gebruikgemaakt van het $d a$ Vinci $^{\circledR}{ }^{\circledR} i^{\mathrm{TM}}$ Surgical System (Intuitive Surgical Inc., Sunnyvale, CA, USA). De procedures worden uitgevoerd met een $30 \mathrm{~g}$-optiek, twee of drie robottrocars (hot shears monopolar curved scissors, een fenestrated bipolar en bij RAPN een large needle driver) met een of twee assistentietrocar(s).

\section{Positionering, poortplaatsing en docken}

De patiënt wordt in een $70-80^{\circ}$ flankpositie gepositioneerd en de tafel wordt geknikt. De benadering is merendeels transperitoneaal, soms retroperitoneaal. Na onder zicht inbrengen van de $12 \mathrm{~mm}$-cameratrocar op de pararectale lijn ongeveer $2 \mathrm{~cm}$ craniaal van de navel, worden twee tot drie $8 \mathrm{~mm}$-robottrocars in waaiervorm gepositioneerd en één assistentietrocar $(12 \mathrm{~mm})$ ingebracht voor onder andere clipplaatsing en afzuigen. Bij een ingreep aan de rechterzijde wordt eventueel nog een tweede assistentietrocar $(5 \mathrm{~mm})$ ingebracht om de lever middels een klem omhoog te houden. De robot wordt van de dorsale zijde over de schouders van patiënt ingereden en gedockt.

\section{Operatie}

Bij RAPN worden de arteria en vena renalis geïdentificeerd en vrijgelegd. De niertumor wordt vrijgeprepareerd en rondom diathermisch geïncideerd. Vervolgens wordt de arterie en zo nodig ook de vene afgeklemd met een tourniquet of robot bulldog (Scanlan, St. Paul, MN, USA), waarna resectie van de tumor plaatsvindt. Nadien wordt de diepe laag van het tumorbed gesloten met een doorlopende PDS 3.0. Early unclamping wordt toegepast, indien mogelijk. De buitenste laag wordt volgens de sliding-cliptechniek gehecht met PDS 2.0 en Hem-o-lok ${ }^{\circledR}$ clips (Teleflex Medical, Kenosha, WI, USA). Ten slotte wordt het preparaat in 
Tabel 1 Patiëntkarakteristieken.

\begin{tabular}{|c|c|c|c|c|}
\hline kenmerk & RAPN $(n)$ & $\%(n=200)$ & $\operatorname{RARN}(n)$ & $\%(n=120)$ \\
\hline $0^{7}$ & 117 & 58,5 & 68 & 56,7 \\
\hline leeftijd: gemiddelde (SD) & 62,0 & $(12,5)$ & 63,0 & $(12,5)$ \\
\hline BMI: gemiddelde (SD) & 27,9 & $(5,2)$ & 28,2 & $(6,2)$ \\
\hline mononier & 5 & 2,5 & 1 & 0,8 \\
\hline \multicolumn{5}{|l|}{ ECOG-classificatie } \\
\hline 0 & 63 & 31,5 & 24 & 20,0 \\
\hline 1 & 54 & 27,0 & 38 & 31,7 \\
\hline 2 & 78 & 39,0 & 43 & 35,8 \\
\hline 3 & 5 & 2,5 & 14 & 11,7 \\
\hline 4 & 0 & 0 & 1 & 0,8 \\
\hline \multicolumn{5}{|l|}{ ASA-classificatie } \\
\hline 1 & 39 & 19,5 & 14 & 11,7 \\
\hline 2 & 129 & 64,5 & 89 & 74,2 \\
\hline 3 & 31 & 15,5 & 17 & 14,2 \\
\hline 4 & 1 & 0,5 & 0 & 0 \\
\hline \multicolumn{5}{|l|}{ Charlson Score } \\
\hline 0 & 85 & 42,5 & 48 & 40,0 \\
\hline $1-2$ & 83 & 41,5 & 54 & 45,0 \\
\hline $3-4$ & 26 & 13,0 & 12 & 10,0 \\
\hline $5-6$ & 5 & 2,5 & 5 & 4,2 \\
\hline $7-8$ & 1 & 0,5 & 1 & 0,8 \\
\hline \multicolumn{5}{|l|}{ Charlson Age Adjusted Score } \\
\hline 0 & 21 & 10,5 & 12 & 10,0 \\
\hline $1-2$ & 70 & 35,0 & 32 & 26,6 \\
\hline $3-4$ & 64 & 32,0 & 49 & 40,9 \\
\hline $5-6$ & 32 & 16,0 & 19 & 15,8 \\
\hline $7-8$ & 12 & 6,0 & 7 & 5,8 \\
\hline $9-10$ & 1 & 0,5 & 1 & 0,8 \\
\hline lokalisatie: links/rechts/bilateraal & $104 / 92 / 4$ & $52,0 / 46,0 / 2,0$ & $68 / 52 / 0$ & $56,7 / 43,3 / 0$ \\
\hline cN0 & 1 & 0,5 & 7 & 5,8 \\
\hline $\mathrm{cM} 0$ & 1 & 0,5 & 7 & 5,8 \\
\hline
\end{tabular}

een endobag geplaatst en wordt de endobag verwijderd via een trocarpoort.

Bij een RARN worden na identificatie van de arteria en vena renalis, deze achtereenvolgens dubbelgeclipt en doorgenomen. De nier wordt rondom vrijgeprepareerd en de ureter wordt eveneens geclipt en doorgenomen. De bijnier wordt gereseceerd wanneer de tumor in de bovenpool van de nier is gelokaliseerd. Het preparaat wordt in een endobag geplaatst en via een verlenging van de insteekopening van een trocar in de onderbuik verwijderd.

Ten slotte wordt een drain over het wondbed gepositioneerd en worden fascie en huid gesloten.

\section{Resultaten}

Bij 200 van de 320 patiënten $(62,5 \%)$ werd een RAPN verricht. Vier patiënten $(3,3 \%)$ met een RARN werden geëxcludeerd omdat peroperatief werd geconverteerd naar een open ingreep.

109 patiënten $(34,5 \%)$ presenteerden zich met lokale symptomen als hematurie of flankpijn, zeven patiënten $(2,2 \%)$ met systemische klachten, maar de meerderheid $(63,3 \%)$ had geen klachten ten tijde van de diagnose. In tab. 1 staan de uitgangswaarden van de 320 patiënten.

Bij RAPN was de mediane klinische (gemeten op CTscan) tumorgrootte $35,0 \mathrm{~mm}$ (IQR = 25,0-48,3), bij RARN 70,0 mm (IQR = 50,0-94,0). Mediane PADUA- en RENAL-scores bedroegen $8(\mathrm{IQR}=7-9)$ en $6,5(\mathrm{IQR}=5-8)$ bij RAPN en 10 (IQR = 9-12) en 9 (IQR = 8-10,5) bij RARN. Tumoren werden beschouwd als complex (PADUA-score 6-7 of RENAL-score 4-6), middencomplex (PADUA-score 8-9 of RENAL-score 7-9) of hoogcomplex (PADUA-score $>10$ of RENAL-score $>10$ ). Zie tab. 2 . 
Tabel 2 PADUA- en RENAL-scores.

\begin{tabular}{llll}
\hline & & RAPN $(n=180)$ & RARN $(n=101)$ \\
\hline PADUA-score & $6-7^{\mathrm{a}}$ (laagcomplex) & $74(41,1)$ & $2(2,0)$ \\
& $8-9^{\mathrm{a}}$ (middencomplex) & $71(39,4)$ & $19(18,8)$ \\
& $>10^{\mathrm{a}}$ (hoogcomplex) & $35(19,4)$ & $80(79,2)$ \\
& mediaan (IQR) & $8(7-9)$ & $10(9-12)$ \\
RENAL-score & $4-6^{\mathrm{a}}$ (laagcomplex) & $91(50,6)$ & $10(9,9)$ \\
& $7-9^{\mathrm{a}}$ (middencomplex) & $76(42,2)$ & $24(23,8)$ \\
& $10-12^{\mathrm{a}}$ (hoogcomplex) & $13(7,2)$ & $67(66,3)$ \\
& mediaan (IQR) & $6,5(5-8)$ & $9(8-10,5)$ \\
\hline
\end{tabular}

${ }^{\mathrm{a}}$ Getallen zijn $n(\%)$.

\section{Peroperatieve uitkomsten}

Bij 98,1\% van de patiënten was de benadering transperitoneaal. Drie $(19,9 \%)$ of vier $(80,1 \%)$ trocars werden geplaatst met een $(91,6 \%)$ of twee assistentietrocars $(8,4 \%)$.

Bij een RAPN bedroeg de mediane operatieduur $133 \mathrm{mi}-$ nuten (IQR = 109-164). De arteria renalis werd bij 98,4\% van de resecties geklemd met een tourniquet $(94,8 \%)$ of bulldog $(3,6 \%)$. De vena renalis werd bij $67,4 \%$ van de resecties geklemd met behulp van een tourniquet $(64,8 \%)$ of bulldog (2,6\%). Mediane warme ischemietijd bedroeg 16 minuten $(\mathrm{IQR}=12-20)$. Early unclamping werd bij $13 \%$ van de resecties toegepast. Het mediane bloedverlies bedroeg $100 \mathrm{ml}$ (IQR = 40-250). Haemostatica, bijvoorbeeld tachosil of surgicel, werden gebruikt bij $6,1 \%$ van de patiënten. Peroperatief trad bij één patiënt $(0,9 \%)$ een kleine colonlaesie op, welke kon worden overhecht. Negen keer werd geconverteerd naar een RARN, omdat de tumor niet kon worden bereikt of vrijgeprepareerd.

De mediane operatieduur bij RARN bedroeg $132 \mathrm{~min}$ $(\mathrm{IQR}=104-163)$ met een mediaan bloedverlies van $75 \mathrm{ml}$ $(\mathrm{IQR}=1,3-200)$. Bij 2,7\% van de patiënten werd gebruikgemaakt van haemostatica in de vorm van tachosil $(1,8 \%)$ of surgicel $(0,9 \%)$. Een lymfeklierdissectie werd bij $11,2 \%$ van de patiënten verricht; bij 45,2\% werd tevens de bijnier verwijderd. Visceraal letsel trad op bij twee patiënten $(1,7 \%)$ : in één geval was sprake van een darmlaesie bij introductie van de cameratrocar door uitgebreide adhesies, bij één patiënt ontstond een pleuralaesie. Beide complicaties konden robotgeassisteerd worden opgelost. Bij vier patiënten werd geconverteerd naar een open ingreep vanwege bloeding $(n=1)$ of het niet veilig kunnen bereiken van de tumor $(n=3)$.

\section{Postoperatieve uitkomsten}

Na RAPN trad een complicatie op bij $25 \%$ van de patiënten. Bij 17,0\% betrof het een laaggradige complicatie (Clavien 1 of 2) en bij 8,0\% een hooggradige complicatie (Clavien 3 of 4). De mediane opnameduur bedroeg drie dagen
(IQR = 2-4), dag 0 was de operatiedag, dag 1 de eerste dag postoperatief et cetera. Na RARN trad een complicatie op bij 10,3\% van de patiënten. Bij 5,1\% betrof het een laaggradige complicatie (Clavien 1 of 2) en bij 5,2\% een hooggradige complicatie (Clavien 3 of 4). De mediane opnameduur bedroeg drie dagen (IQR $=2,3-4,0$ ).

In tab. 3 en 4 zijn de postoperatieve uitkomsten nader gespecificeerd.

\section{Pathologie}

De pathologische grootte van de tumor was $32 \mathrm{~mm}$ (IQR = 23-44) in de RAPN-groep en $68 \mathrm{~mm}$ (IQR $=49,5-90)$ in de RARN-groep. Bij $78 \%$ van de patiënten in de RAPN-groep en $86,2 \%$ in de RARN-groep betrof het maligne tumoren.

Bij 79,7\% van de patiënten werd een heldercellig $(n=$ 204), bij $12,1 \%$ een papillair $(n=31)$ en bij $7,4 \%$ een chromofoob $(n=19)$ carcinoom gevonden. De rest van de patiënten $(0,8 \% ; n=2)$ viel in de restcategorie. De Fuhrman-gradering is weergegeven in tab. 5, de T-classificatie in fig. 1. Een positief snijvlak werd gevonden bij 19 van de 156 maligniteiten (12,2\%) in de RAPN-groep en een positief snijvlak ter plaatse van het resectievlak van de vena renalis bij vijf van de $100(5 \%)$ maligniteiten in de RARN-groep. Bij zes patiënten $(5,2 \%)$ die een RARN ondergingen, werd lymfogene metastasering pathologisch vastgesteld.

De benigne tumoren werden geclassificeerd als een oncocytoom $(n=22 ; 36,7 \%)$, een angiomyolipoom $(n=$ $13 ; 21,7 \%)$, xanthogranulomateuze pyelonefritis $(n=5$; $8,3 \%)$, een benigne cyste $(n=5 ; 8,3 \%)$ en restcategorie $(n=15 ; 25,0 \%)$.

\section{Follow-up}

De mediane follow-up was 12 maanden (IQR $=3-24$ ) bij patiënten die een RAPN en 10 maanden (IQR $=1,5-27,3$ ) bij patiënten die een RARN ondergingen.

De GFR in de RAPN-groep was van $83 \mathrm{~mL} / \mathrm{min} / 1,73 \mathrm{~m}^{2}$ $(\mathrm{IQR}=69-106)$ preoperatief gedaald naar $72(\mathrm{IQR}=$ 
Tabel 3 Postoperatieve complicaties na een RAPN.

\begin{tabular}{ll}
\hline Clavien-Dindograad & $\begin{array}{l}\mathrm{RAPN}^{*} \\
(n=200)\end{array}$ \\
\hline 1 & $13(6,5)$ \\
2 & $21(10,5)$ \\
3 & $9(4,5)$ \\
4 & $7(3,5)$
\end{tabular}

* Getallen zijn $n(\%)$.

${ }^{\mathrm{b}}$ Restcategorie:pneumothorax, pneumonie, longembolie, darmperforatie, gastro-enteritis, analgetica intoxicatie, laag $\mathrm{Hb}$, geoccludeerde arteria renalis links op basis van een intraluminale trombus, subfebriliteit, urineweginfectie, stolselretentie blaas, bundeltakblok, heropname in verband met pijn.
Tabel 4 Postoperatieve complicaties na een RARN

\begin{tabular}{ll}
\hline Clavien-Dindograad & $\begin{array}{l}\text { RARN }^{*} \\
(n=116)\end{array}$ \\
\hline 1 & $2(1,7)$ \\
2 & $4(3,4)$ \\
3 & $3(2,6)$ \\
4 & $3(2,6)$
\end{tabular}

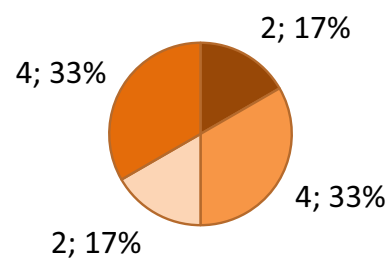

— lymfelekkage

$\square$ koorts

$\square$ ileus

restcategorie ${ }^{b}$

${ }^{*}$ Getallen zijn $n(\%)$.

${ }^{\mathrm{b}}$ Restcategorie: pneumothorax, pneumonie, analgetica intoxicatie, abces.

56-88) drie maanden postoperatief $(p<0,001)$. Daarna bleef de nierfunctie in de RAPN-groep stabiel; een jaar postoperatief bedroeg de GFR $69 \mathrm{~mL} / \mathrm{min} / 1,73 \mathrm{~m}^{2}$ (IQR = 56-85). Op het moment van schrijven van dit artikel waren 137 van de 149 patiënten $(91,9 \%)$ ziektevrij. Bij drie patiënten $(2 \%)$ werd tijdens de follow-up een lokaal recidief vastgesteld waarvoor deze patiënten een radicale nefrectomie moesten ondergaan. Eén patiënt $(0,7 \%)$ die een RAPN onderging, bleek gemetastaseerd. Deze patiënt had een voorgeschiedenis van een niertumor aan de contralaterale zijde, waarvoor elders een laparoscopische radicale nefrectomie (LRN) was verricht. Eén patiënt $(0,7 \%)$ die voorafgaand aan de RAPN reeds een botmetastase had ten gevolge van niercelcarcinoom, overleed ten gevolge van nierkanker. Het betrof een pT1aNOM1-niertumor van $1,8 \mathrm{~cm}$ die radicaal werd verwijderd. Alle 19 patiënten met een positief snijvlak waren aan het einde van de followupperiode ziektevrij.

In de RARN-groep bedroeg de preoperatieve GFR $79,0 \mathrm{~mL} / \mathrm{min} / 1,73 \mathrm{~m}^{2}$ (IQR = 62-96) en de postoperatieve GFR na drie maanden $47 \mathrm{~mL} / \mathrm{min} / 1,73 \mathrm{~m}^{2}$ $(\mathrm{IQR}=36-58 ; p<0,001)$. Ook in deze groep bleef de

Tabel 5 Fuhrman-gradering.

\begin{tabular}{lll}
\hline fuhrman-gradering & RAPN $^{* a}(n=141)$ & RARN $^{*}(n=101)$ \\
\hline 1 & $30(21,3)$ & $2(2,0)$ \\
2 & $97(68,8)$ & $19(18,8)$ \\
3 & $13(9,2)$ & $80(79,2)$ \\
4 & $1(0,7)$ & - \\
\hline
\end{tabular}

${ }^{\mathrm{a}}$ Getallen zijn $n(\%)$. nierfunctie postoperatief stabiel; de GFR was 12 maanden postoperatief $45 \mathrm{~mL} / \mathrm{min} / 1,73 \mathrm{~m}^{2}$ (IQR $\left.=34-58\right) .67$ van de 90 patiënten $(74,4 \%)$ waren aan het eind van de followupperiode ziektevrij. Bij zes patiënten $(6,7 \%)$ was sprake van ziekteprogressie na RARN. Zeven patiënten $(7,8 \%)$ overleden door nierkanker, van wie drie preoperatief al metastasen hadden. Van de vijf patiënten met een positief snijvlak waren aan het eind van de follow-upperiode twee patiënten nog ziektevrij, één patiënt had preoperatief al metastasen, twee patiënten ontwikkelden deze postoperatief.

\section{Uitkomsten van RAPN, rekening houdend met de complexiteit van de tumor}

Naarmate de tumorcomplexiteit toenam, namen ook bloedverlies en operatieduur toe. Mediane ischemietijd bleef echter gelijk bij resectie van midden- en hoogcomplexe tumoren. Er lijkt geen verband tussen tumorcomplexiteit en het aantal complicaties. Wel werd minder vaak een positief snijvlak gezien bij resectie van een hoogcomplexe tumor ten opzichte van een laag- of middencomplexe tumor. Zie tab. 6.

\section{Ervaring}

Bij de patiënten bij wie een RARN is uitgevoerd, lijkt geen verband tussen ervaring van het centrum en de operatieduur, bloedverlies, complicaties of het aantal tumoren met een positief snijvlak. Zie tab. 7. 

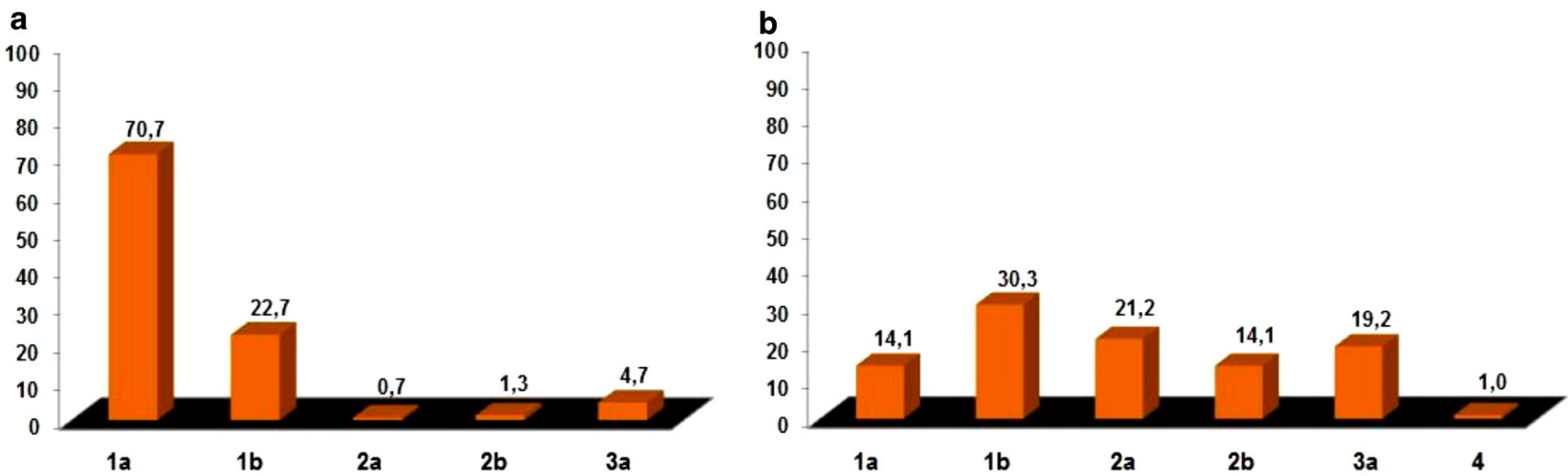

Figuur 1a,b T-classificatie.

Tabel 6 Uitkomsten RAPN waarbij rekening is gehouden met tumorcomplexiteit.

\begin{tabular}{|c|c|c|c|c|c|c|}
\hline & \multirow{2}{*}{$\begin{array}{l}\text { operatieduur } \\
\text { in } \min ^{\mathrm{a}}\end{array}$} & \multirow{2}{*}{$\begin{array}{l}\text { ischemietijd } \\
\text { in } \min ^{\mathrm{a}}\end{array}$} & \multirow{2}{*}{$\begin{array}{l}\text { bloedverlies } \\
\text { in } \mathrm{ml}^{\mathrm{a}}\end{array}$} & \multicolumn{2}{|c|}{ complicaties } & \multirow{2}{*}{$\begin{array}{l}\text { positief } \\
\text { snijvlak }^{\mathrm{b}}\end{array}$} \\
\hline & & & & laagrisico $^{\mathrm{b}}$ & hoogrisico $^{\mathrm{b}}$ & \\
\hline \multicolumn{7}{|c|}{ PADUA-score } \\
\hline $6-7$ & $\begin{array}{l}116,0 \\
(93,8-147,5)\end{array}$ & $\begin{array}{l}13 \\
(11-18)\end{array}$ & $\begin{array}{l}50 \\
(20-200)\end{array}$ & $\begin{array}{l}11 \\
(14,9)\end{array}$ & $\begin{array}{l}9 \\
(12,2)\end{array}$ & $\begin{array}{l}8 \\
(10,8)\end{array}$ \\
\hline $8-9$ & $\begin{array}{l}140,0 \\
(123,0-172,0)\end{array}$ & $\begin{array}{l}18 \\
(14-22)\end{array}$ & $\begin{array}{l}100 \\
(50-300)\end{array}$ & $\begin{array}{l}7 \\
(9,9)\end{array}$ & $\begin{array}{l}4 \\
(5,6)\end{array}$ & $\begin{array}{l}7 \\
(9,9)\end{array}$ \\
\hline$>10$ & $\begin{array}{l}145,0 \\
(116,0-175,0)\end{array}$ & $\begin{array}{l}18 \\
(15-25)\end{array}$ & $\begin{array}{l}200 \\
(100-300)\end{array}$ & $\begin{array}{l}11 \\
(31,4)\end{array}$ & $\begin{array}{l}2 \\
(5,7)\end{array}$ & $\begin{array}{l}4 \\
(11,4)\end{array}$ \\
\hline \multicolumn{7}{|c|}{ RENAL-score } \\
\hline $4-6$ & $\begin{array}{l}127,0 \\
(100,0-164,0)\end{array}$ & $\begin{array}{l}15 \\
(12-19)\end{array}$ & $\begin{array}{l}50 \\
(20-200)\end{array}$ & $\begin{array}{l}12 \\
(13,2)\end{array}$ & $\begin{array}{l}9 \\
(9,9)\end{array}$ & $\begin{array}{l}12 \\
(13,2)\end{array}$ \\
\hline $7-9$ & $\begin{array}{l}136,5 \\
(113,3-154,0)\end{array}$ & $\begin{array}{l}18 \\
(14-22)\end{array}$ & $\begin{array}{l}100 \\
(50-250)\end{array}$ & $\begin{array}{l}14 \\
(18,5)\end{array}$ & $\begin{array}{l}6 \\
(7,9)\end{array}$ & $\begin{array}{l}6 \\
(7,9)\end{array}$ \\
\hline $10-12$ & $\begin{array}{l}153,0 \\
(125,0-169,5)\end{array}$ & $\begin{array}{l}18 \\
(13,5-21,5) \\
\end{array}$ & $\begin{array}{l}150 \\
(100-450) \\
\end{array}$ & $\begin{array}{l}3 \\
(23,1) \\
\end{array}$ & - & $\begin{array}{l}1 \\
(7,7)\end{array}$ \\
\hline
\end{tabular}

${ }^{\mathrm{a}}$ Getallen zijn mediaan (IQR).

${ }^{\mathrm{b}}$ Getallen zijn $n(\%)$.

\section{Beschouwing}

Doel van deze studie was de per- en postoperatieve uitkomsten van robotgeassisteerde chirurgie bij niertumoren in een hoogvolumecentrum te evalueren. Bij RAPN zijn de uitkomsten verder gespecificeerd naar complexiteit van de tumor en bij RARN naar ervaring van het centrum.

Volgens de richtlijnen van de European Association of Urology (EAU) uit 2015 kan een partiële nefrectomie open, laparoscopisch of robotgeassisteerd worden uitgevoerd [1]. Twee recentelijk gepubliceerde, grote meta-analyses concluderen dat de RAPN op meerdere vlakken superieur is ten opzichte van een open partiële nefrectomie of laparoscopische partiële nefrectomie. Zo zien Wu et al. bij 3.418 patiënten dat de RAPN $(n=757)$ gepaard gaat met significant minder bloedverlies, minder per- en postoperatieve complicaties en een kortere opnameduur ten opzichte van een open par- tiële nefrectomie ( $n=2.661)$ [12]. Ischemietijd, conversie naar een radicale nefrectomie, GFR-verandering en oncologische uitkomsten bleken vergelijkbaar. Choi et al. vonden bij 2.240 patiënten bij wie een RAPN of laparoscopische partiële nefrectomie was verricht, dat bij RAPN de ischemietijd significant korter is, evenals de opnameduur, en dat de nierfunctie beter behouden blijft in vergelijking met een laparoscopische partiële nefrectomie [13]. Daarnaast was hun bevinding dat bij RAPN minder vaak wordt geconverteerd naar een open ingreep en dat er geen verschil was in hoog- of laaggradige complicaties, operatieduur, geschat bloedverlies of het percentage met een positief snijvlak [13].

Ook uit deze RAPN-serie blijken een korte operatie- en ischemietijd met minimaal bloedverlies en een korte opnameduur. Er is niet geconverteerd naar een open ingreep. Slechts bij $8 \%$ van de patiënten treedt postoperatief een hooggradige complicatie op. De follow-up is pas kort, maar 
Tabel 7 Uitkomsten RARN, waarbij rekening is gehouden met de ervaring van het centrum.

\begin{tabular}{|c|c|c|c|c|c|}
\hline \multirow[t]{2}{*}{ ingreep } & \multirow[t]{2}{*}{ operatieduur in $\min ^{\mathrm{a}}$} & \multirow[t]{2}{*}{ bloedverlies in $\mathrm{ml}^{\mathrm{a}}$} & \multicolumn{2}{|l|}{ complicaties } & \multirow[t]{2}{*}{ positief snijvlak $^{b}$} \\
\hline & & & laag risico ${ }^{\mathrm{b}}$ & hoog risico ${ }^{b}$ & \\
\hline $1-39$ & $\begin{array}{l}136,5 \\
(106,5-186,0)\end{array}$ & $\begin{array}{l}50 \\
(0-200)\end{array}$ & $\begin{array}{l}2 \\
(5,2)\end{array}$ & $\begin{array}{l}2 \\
(5,1)\end{array}$ & $\begin{array}{l}1 \\
(2,6)\end{array}$ \\
\hline $40-78$ & $\begin{array}{l}123,0 \\
(104,0-161,0)\end{array}$ & $\begin{array}{l}50 \\
(0-100)\end{array}$ & $\begin{array}{l}3 \\
(7,7)\end{array}$ & $\begin{array}{l}2 \\
(5,1)\end{array}$ & $\begin{array}{l}4 \\
(10,3)\end{array}$ \\
\hline 79-116 & $\begin{array}{l}131,0 \\
(100,8-178,5)\end{array}$ & $\begin{array}{l}100 \\
(50-250)\end{array}$ & $\begin{array}{l}2 \\
(5,2)\end{array}$ & $\begin{array}{l}2 \\
(5,1)\end{array}$ & - \\
\hline
\end{tabular}

${ }^{\mathrm{a}}$ Getallen zijn mediaan (IQR).

${ }^{\mathrm{b}}$ Getallen zijn $n(\%)$.

de eerste oncologische uitkomsten zijn gunstig. Slechts $2,7 \%$ van de patiënten ontwikkelt een lokaal recidief of metastasen, één patiënt overlijdt. Een positief snijvlak lijkt vooralsnog niet relevant; bij geen enkele patiënt met een positief snijvlak is namelijk sprake van ziekteprogressie na de operatie. Dit is conform de literatuur; uit een review blijkt dat een positief snijvlak niet wordt geassocieerd met een verhoogde kans op metastasering of een verminderde overleving [14].

Midden- en hoogcomplexe tumoren kunnen eveneens veilig middels een RAPN worden gereseceerd. Volpe et al. hebben vergelijkbare peroperatieve uitkomsten bij 44 hoogcomplexe tumoren waarbij een RAPN is verricht [15]. Opvallend in onze resultaten is de gelijke, korte ischemietijd bij resectie van midden- en hoogcomplexe tumoren. Mogelijk komt dit doordat de contour van de tumor voor het afklemmen van de vaten reeds diathermisch wordt gemarkeerd. Daarbij wordt steeds vaker early unclamping toegepast. Ook spelen de leercurve en patiëntenselectie wellicht een rol; naarmate de leercurve toeneemt, zijn wellicht complexere tumoren middels RAPN gereseceerd. Bij resectie van hoogcomplexe tumoren wordt minder vaak een positief snijvlak gezien. Mogelijk worden complexere tumoren zekerheidshalve met een ruimere marge verwijderd.

Bij een radicale nefrectomie gaat de voorkeur uit naar laparoscopie, omdat de peroperatieve uitkomsten beter zijn dan bij een open ingreep [1-3, 5, 9, 10, 16]. Laparoscopie betekent echter werken met een tweedimensionaal beeld, minder bewegingsvrijheid, verslechtering van de ergonomie en ook wordt de natuurlijke oog-handcoördinatie bemoeilijkt doordat de instrumenten moeten worden bewogen in tegenovergestelde richting van het doel, bekend als het fulcrumeffect $[6,8,11,16]$. Wellicht bepalen deze factoren waarom relatief weinig urologen laparoscopie in de dagelijkse praktijk toepassen $[5,10]$. De robot heeft de voordelen van minimaal invasieve chirurgie en biedt tegelijkertijd de oplossing voor de tekortkomingen van de laparoscopie [6, 8-10].

Er zijn slechts enkele studies die de robottechnologie met laparoscopie vergelijken bij een radicale nefrectomie [17]. Meerwaarde van de robot is vooralsnog niet aangetoond
[17]. Zo zien Hemal et al. een significant kortere operatieduur in de laparoscopische groep, terwijl opnameduur en analgeticagebruik gelijk zijn [5]. Boger et al. concluderen dat de robottechnologie geen voordelen oplevert ten opzichte van een laparoscopische of hand-assisted laparoscopische ingreep [18]. In beide studies betreft het echter een kleine studiepopulatie. Daarbij is in de studie van Boger het aantal patiënten met een maligniteit veel hoger in de robotgroep dan in de andere groepen [18]. Ten slotte is de vraag hoeveel ervaring de operateur met laparoscopie en robot reeds heeft opgedaan.

De robot lijkt wel degelijk voordelen te bieden wanneer we onze resultaten van 116 RARN vergelijken met een andere studie met 101 RARN en deze resultaten afzetten tegen de uitkomsten van twee studies met respectievelijk 125 en 482 laparoscopische radicale nefrectomieën [10, 16, 19]. $\mathrm{Zo}$ is de gemiddelde operatieduur bij beide LRN-studies respectievelijk 28 en 16 minuten langer dan in de andere RARN-studie [10, 16, 19]. Ook het bloedverlies is $143 \mathrm{ml}$ meer in de LRN-studie $[10,16]$. Intraoperatieve complicaties treden op bij respectievelijk $2,4 \%$ en $6 \%$ van de patiënten in de LRN-studies versus $1,7 \%$ van de patiënten in onze populatie $[16,19]$. Laparoscopisch wordt bij $1,6 \%$ en $9,4 \%$ van de resecties geconverteerd naar een open ingreep; in onze populatie bij 3,3\% van de resecties en in de andere RARN-studie wordt zelfs helemaal niet geconverteerd [10, 16, 19]. De gemiddelde opnameduur bedraagt zes en 5,4 dagen in de laparoscopische studies, terwij1 $94 \%$ van de patiënten in de andere RARN-studie op de operatiedag zelf of de dag erna naar huis kan [10, 16, 19]. Onze mediane opnameduur is weliswaar langer dan in de andere RARN-studie, maar nog altijd korter dan in de laparoscopische studies [10, 16, 19]. In onze populatie wordt vaker een positief snijvlak geconstateerd dan in de andere RARN- en LRN-studie [10, 16, 19]. Wel was bij één patiënt sprake van een palliatieve nefrectomie, een andere patiënt had preoperatief reeds een tumortrombus. Gemiddelde pathologische tumorgrootte was $5,1 \mathrm{~cm}$ in de LRNstudie versus 8,2 centimeter in de andere RARN-studie [ 10 , 16]. Onze mediane tumorgrootte zit met $6,8 \mathrm{~cm}$ ertussenin. Ziekteprogressie wordt bij drie patiënten in de LRN-studie, 
bij twee patiënten in de RARN-studie en bij zes patiënten in onze populatie gezien $[10,16]$.

Uit onze resultaten blijkt geen verband tussen ervaring van het centrum en operatieduur, bloedverlies, complicaties of een positief snijvlak. Beide LRN-studies constateren wel minder vaak intraoperatieve complicaties naarmate de ervaring van de operateur toeneemt. Wellicht komt dit door een langere leercurve bij de laparoscopie $[8,11,16]$.

In de praktijk bepalen tumorlocatie, habitus van de patiënt, intra-abdominale chirurgie in de voorgeschiedenis en intrinsieke factoren, zoals persoonlijke voorkeur, bedrevenheid met de techniek en de leercurve, de uiteindelijke keuze voor de benadering [3]. Hoewel de robottechnologie veelbelovend is, blijft toepassing van robotchirurgie tot op de dag van vandaag controversieel $[8,10]$. Met name de hoge kosten lijken het grootste obstakel voor verdere ingebruikneming van de robot; aanschaf, peroperatief gebruik van instrumenten en materialen, opleiding van een gespecialiseerd team en eventuele aanpassingen in de operatiekamer maken de robot immers duurder dan een laparoscopische of open ingreep [5, 8-10]. Anderzijds is vrijwel de gehele gezondheidszorg duurder geworden [20]. Nieuwe therapieën gaan nu eenmaal gepaard met hogere kosten dan de conventionele [20]. De vraag is of een revolutionaire ontwikkeling op chirurgisch vlak aan patiënten mag worden onthouden omwille van de kosten [20]. Ten slotte zal moeten blijken of de robot daadwerkelijk duurder is dan een open of laparoscopische ingreep [12]. Een kortere operatie- en opnameduur kunnen wellicht de hogere kosten (gedeeltelijk) compenseren. Uiteindelijk bepalen vaardigheid en ervaring van de operateur het succes van de ingreep, ongeacht of de operatie open, laparoscopisch of robotgeassisteerd wordt uitgevoerd $[10,20]$.

\section{Sterke punten, beperkingen en aanbevelingen.}

Het betreft een grote studie van Nederlandse bodem. Onze RARN-serie is zelfs uniek qua grootte; de recentelijk gepubliceerde studie met 101 RARN is omschreven als de grootste serie wereldwijd [10]. Behalve naar per- en postoperatieve uitkomsten is ook gekeken naar oncologische uitkomsten en zijn de invloed van tumorcomplexiteit op de resultaten bij RAPN en de ervaring van de operateur bij RARN vastgesteld. De meest relevante tekortkoming is de relatief korte follow-up; oncologische uitkomsten op lange termijn ontbreken vanwege de korte beschikbaarheid van de robot. Ook is niet gekeken naar de kwaliteit van leven van de patiënten na de operatie en de daadwerkelijke herstelperiode van de individuele patiënt. De resultaten van meerdere urologen tezamen zijn weergegeven. Hierbij is geen rekening gehouden met de leercurve van de individuele operateur. Vervolgonderzoek waarbij prospectief peroperatieve en oncologische uitkomsten van open, laparoscopische en robotgeassisteerde chirurgie bij niertumoren op langere termijn met elkaar worden vergeleken, is nodig om de definitieve waarde van de robot vast te stellen.

\section{Conclusie}

Dankzij robotgeassisteerde chirurgie kunnen niertumoren op minimaal invasieve wijze veilig gereseceerd worden. Operatieduur, ischemietijd en opnameduur zijn kort, het bloedverlies is minimaal en het aantal complicaties is acceptabel, ook bij de complexere tumoren. Oncologische uitkomsten zijn gunstig; slechts bij weinig patiënten is sprake van ziekteprogressie na de operatie.

Open Access This article is distributed under the terms of the Creative Commons Attribution 4.0 International License (http:// creativecommons.org/licenses/by/4.0/), which permits unrestricted use, distribution, and reproduction in any medium, provided you give appropriate credit to the original author(s) and the source, provide a link to the Creative Commons license, and indicate if changes were made.

\section{Literatuur}

1. Ljungberg B, Bensalah K, Bex A, et al. Guidelines on Renal Cell Carcinoma. European Association of Urology. 2015

2. Richtlijnen voor oncologische zorg. Oncoline. www.oncoline.nl, geraadpleegd op 31 oktober 2015.

3. MacLennan S, Imamura M, Lapitan MC, et al. Systematic review of perioperative and quality-of-life outcomes following surgical management of localised renal cancer. Eur Urol. 2012;62(6):1097-117.

4. Bangma C. Leerboek urologie, $3^{\mathrm{e}}$ ed. Houten: Bohn Stafleu van Loghum; 2013.

5. Hemal AK, Kumar A. A prospective comparison of laparoscopic and robotic radical nephrectomy for T1-2N0M0 renal cell carcinoma. World J Urol. 2009;27(1):89-94.

6. Ficarra V, Bhayani S, Porter J, et al. Predictors of warm ischemia time and perioperative complications in a multicenter, international series of robot-assisted partial nephrectomy. Eur Urol. 2012;61(2):395-402.

7. Iannetti A, Gnech M, Rossanese M, et al. Robot-assisted renal surgery: current indications and results. Minerva Urol Nefrol. 2014;66(1):15-24.

8. Lanfranco AR, Castellanos AE, Desai JP, Meyers WC. Robotic surgery: a current perspective. Ann Surg. 2004;239(1):14-21.

9. Jain S, Gautam G. Robotics in urologic oncology. J Minim Access Surg. 2015;11(1):40-4.

10. Petros FG, Angell JE, Abaza R. Outcomes of robotic nephrectomy including highest-complexity cases: largest series to date and literature review. Urology. 2015;85(6):1352-8.

11. Patel HD, Mullins JK, Pierorazio PM, et al. Trends in renal surgery: robotic technology is associated with increased use of partial nephrectomy. J Urol. 2013;189(4):1229-35.

12. Wu Z, Li M, Liu B, et al. Robotic versus open partial nephrectomy: a systematic review and meta-analysis. PLoS ONE. 2014;Apr;16;9(4)

13. Choi JE, You JH, Kim DK, Rha KH, Lee SH. Comparison of perioperative outcomes between robotic and laparoscopic partial 
nephrectomy: a systematic review and meta-analysis. Eur Urol. 2015;67(5):891-901.

14. Borghesi M, Brunocilla E, Schiavina R, Martorana G. Positive surgical margins after nephron-sparing surgery for renal cell carcinoma: incidence, clinical impact, and management. Clin Genitourin Cancer. 2013;11(1):5-9.

15. Volpe A, Garrou D, Amparore D, et al. Perioperative and renal functional outcomes of elective robot-assisted partial nephrectomy (RAPN) for renal tumours with high surgical complexity. BJU Int. 2014;114(6):903-9.

16. Wille AH, Roigas J, Deger S, Tüllmann M, Türk I, Loening SA. Laparoscopic radical nephrectomy: techniques, results and oncological outcome in 125 consecutive cases. Eur Urol. 2004;45(4):483-8.

17. Asimakopoulos AD, Miano R, Annino F, et al. Robotic radical nephrectomy for renal cell carcinoma: a systematic review. BMC Urol. 2014; 14:75.

18. Boger M, Lucas SM, Popp SC, Gardner TA, Sundaram CP. Comparison of robot-assisted nephrectomy with laparoscopic and handassisted laparoscopic nephrectomy. JSLS. 2010;14(3):374-80.
19. Rassweiler J, Fornara P, Weber M, et al. Laparoscopic nephrectomy: the experience of the laparoscopy working group of the German Urologic Association. J Urol. 1998;160(1):18-21.

20. Mottrie AM. The introduction of robot-assisted surgery in urologic practice: why is it so difficult? Eur Urol. 2010;57(5):747-9.

drs. Lucy K. Pellikaan anios urologie

drs. Melanie Gan uroloog

drs. Patrick Leenen epidemioloog

dr. Dies van den Ouden uroloog

drs. O. Sjoerd Klaver uroloog

drs. Roel Engel uroloog

drs. Diederik C.D. de Lange uroloog 